\title{
FORECASTING OF NET PROFIT AND THE AREA OF LAND OF PRIVATE ENTERPRISES
}

\author{
Diana Shelenko* 1, Ivan Balaniuk ${ }^{2}$, Liudmyla Sas ${ }^{3}$, Mykola Malik $^{4}$, Petro Matkovskyi ${ }^{5}$, Omelian \\ Levandivskyi ${ }^{6}$, Mariana Humeniuk ${ }^{7}$
}

${ }^{1}$ Prof. Dr. Vasyl Stefanyk Precarpathian National University, 57, Shevchenka st. 76010, Ivano-Frankivsk, Ukraine, Phone No.: +380990662326, E-mail address: diana.shelenko@pnu.edu.ua

${ }^{2}$ Prof. Dr. Vasyl Stefanyk Precarpathian National University, 57, Shevchenka st. 76010, Ivano-Frankivsk, Ukraine, Phone No.: +380503733282, E-mail address: ifbalaniuk@gmail.com

3 Prof. Dr. Vasyl Stefanyk Precarpathian National University, 57, Shevchenka st. 76010, Ivano-Frankivsk, Ukraine, phone: +380503714824, E-mail address: liudmyla.sas@pnu.edu.ua

${ }^{4}$ Prof. Dr., National Scientific Centre 10, Heroiv Oborony St., 03127 Kyiv, Ukraine, Phone No.: +380973479579, Email address: malik_coop@iae.org.ua

${ }^{5}$ Prof. Dr. Vasyl Stefanyk Precarpathian National University, 57, Shevchenka st. 76010, Ivano-Frankivsk, Ukraine, Phone No.: +3801358218 E-mail address: petromatkovskyy@gmail.com

${ }^{6}$ Prof. Dr. Vasyl Stefanyk Precarpathian National University, 57, Shevchenka st. 76010, Ivano-Frankivsk, Ukraine, Phone No.: +380509413217, E-mail address: omelyant@ukr.net

7 Senior Researcher, PhD of Economics, Precarpathian State Agricultural Experimental Station of the Agricultural Institute in Carpathion Region of NAAS, 21-A Bandera str., 76000, Ivano- Frankivsk, Ukraine, Phone No.: +380979000963, E-mail address: maryana.gumenyuk@gmail.com

Received 0108 2021; Accepted 05082021

\begin{abstract}
The article is devoted to the forecasting of net profit of private enterprises of Ukraine with application of STELLA program. The STELLA economic modeling program, which combines mathematical differential equations with a developed graphical interface, has been used in the article. In this program a model was created, and an attempt was made to forecast the private enterprises of Ukraine by 2030. It has been the possible growth up net profit of private enterprises with a slight reduction and further stabilization of the agricultural land (AREA) at the level of 45000 thousand hectares and enterprises (ENTERPISES) at the level of 3600. The most promising possibilities of applying STELLA program in economic forecasting has been outlined in the article.
\end{abstract}

Keywords: cost price; private enterprises; STELLA software; net profit forecasting.

JEL Classification: H82, O21, Q12.

\section{Introduction}

Economic activity in the field of agriculture is represented by a wide range of organizational and legal forms of management, where a large part (more than $30 \%$ ) of the use of agricultural land is owned by private enterprises. Entrepreneurship activity in Ukraine is becoming more widespread every year among business entities. This is facilitated by the development and gradual approval of private enterprises to increase the efficiency of their activity.

Copyright $(02021$ Author(s), published by Vytautas Magnus University. This is an open access article distributed under the terms of the Creative Commons Attribution Non-Commercial 4.0 (CC BY-NC 4.0) license, which permits unrestricted use, distribution, and reproduction in any medium provided the original author and source are credited. The material cannot be used for commercial purposes. 
A private enterprise, as interpreted by the Economic Code of Ukraine (2003), is an enterprise that operates based on the private property of one or more citizens, foreigners, stateless persons and its (their) work or with the use of hired labour (Economic Code, 2003). Regardless of the differences in the name or characteristics of the activity of these economic entities, they are united by such a common feature as employment in agricultural production and obtaining profit which can be used for development of production, for strengthening of integration processes and development of cooperation. In the activity of private enterprises determine the trends that set the vector of the movement of economic processes and forecast development indicators for the future, because they reflect economic expectations in the agrarian sector of the economy in accordance with the resulting stable economic ratios, properties, features, characteristic of this sector of the economy, which identify their positive or negative impact on its structural elements, which are private enterprises. The correlation of trends indicates the presence of problems that need urgent solution: insufficient forecasting of the development of private enterprises and imperfection of the system of settlements between the producers themselves. J. K. Clark, D. K. Munro, B. Mansfield (2010) study problems faced by private enterprises in a market economy and argue that their willingness and ability to function in a competitive environment is governed by social relations with agriculture. Investigating the impact of territories, where private enterprises conduct their activity scientists prove that it is the region that offers space of opportunities and provides their adaptability. Such scientists as Balaniuk I., Kyrylenko V., Chaliuk Y., Sheiko Y., Begun S., Diachenko L. (2021b) conduct a comprehensive assessment and generalization of territorial differentiation of socio-economic conditions of development of private enterprises.

The current state of development of Ukrainian private enterprises is characterized by a number of negative and positive phenomena. Negative can be attributed to insufficient growth rates of agricultural production; their low solvency (Gupta, 2019).

M. M. Babich (2007) also determines the main shortcomings of the legal support of agriculture in Ukraine emphasizes: instability and contradictions of the current normative and legal framework; practically nonfunctional nature of many regulations; the existence of fuzzy rules in the law that can be interpreted in different ways, and the unreasonableness of legislative restrictions.

The positive aspects of the development of private enterprises include cooperation with large enterprises; production diversification; rapid manoeuvrability, customer-specific targeting; formation of a real price for their products; adjustment of internal mechanisms of enterprise development (Balaniuk, 2019); establishing industrial and commercial relationships with customers and suppliers. The advantages of private enterprises in comparison to households are also possibility of greater use of mechanization of economic processes, which will increase efficiency (Yakubiv and Boryshkevych, 2018) and competitiveness in the market environment in the end.

Cooperation and integration on the base of business partnership should be considered as important stage for the development of private enterprises (Pylypiv et al., 2018), including partnership with local peculiarities, economic diagnostics and development of specialized strategies will stimulate the economic growth of enterprises. The propositions, concerning the collaboration of enterprise will provide the search of approaches how to find ways to work on this and indicate the large and complex amount of work that needs to be done in general and every case.

That is, solving the existing problems facing private enterprises today requires a reorientation of both public policy on their development and the thinking of private enterprises' managers (moving from making short-term decisions to strategically striving 
for competitive advantage in the market), will depend on the results of their work.

The state and prospects of economic development depend on the level of stability of economic management. As you know that favourable conditions for the manifestation of economic management methods are inherent in the market environment in which private enterprises operate. It is market relations that meet the principles of independence, profitability, responsibility, and austerity. Therefore, managers of private enterprises need to forecast their activities.

Management of complex systems in the conditions of development of private enterprises requires the use of information technologies that provide a reflection of the state and facilitate the management of the system in real time. D. Medouz (2018), a researcher in system dynamics, believes that it is worth using system thinking, not mistakenly thinking that every problem has a simple cause and a quick solution. In her understanding, the system is more than just the sum of its components, and the links in the systems are realized through information flows.

The application of simulation modeling which is based on the model of enterprise advertising strategies (Sokolovska et al., 2018), and was presented using a mathematical apparatus and using the simulation approach in the modeling process, are scientifically grounded. The model is implemented on the platform of AnyLogic multitasking simulation system.

Forecasting can be static for the system state in the future at a certain limit of the interval of advance or dynamic, that is, to simulate the process of modification of the system for the entire interval of advance, which includes the computational tasks that determine the discrete states of the system at certain stages or moments of development of the system in certain variants, and continuous the process of system operation according to the possible scenarios (Peregudov et al., 2009).

New trends in the modern development of private enterprises also require changes in their model. Innovation model of the development of private enterprise, according to foreign authors J. M. Blazy, P. Tixier, A. Thomas, H. Ozier-Lafontaine, F. Salmon, J. Wery (2010) is more commonly used in the design and evaluation of agricultural systems to estimate innovations over a certain period with small resources. The processes that take place in the model are optimization and, in the future, will allow managers of different organizational and legal forms of agricultural enterprises to properly select alternative production capacities. At the same time, the positive aspects of doing business in a social market economy will be manifested in honesty and concluding conflict management (Frańczuk, 2019). Given the performance of the system model, it is not possible to plan and develop anything without a critical assessment of possible future results, especially for the agricultural sector, where destabilizing effects are possible from an unsuccessful decision.

Analysis of scientific works of domestic and foreign scientists, comparison of the experience of scientists who have tried methods of forecasting in different spheres of human life have allowed to form a scientific basis for the application of models of system dynamics, which is an effective practical tool for choosing a researcher appropriate for his purposes the way of scientific forecasting. The STELLA software fully allows you to see the specifics of different directions and modifications of forecasting methods, their variety, properties, relationships and dependencies; recommend building a predictive model for agriculture.

The dynamics of complex systems since the 1930s has been actively developing at the Massachusetts Institute of Technology. W. Bush has created a differential analysis designed to solve equations to describe certain types of simple engineering 
problems. Such a set of equations is a model of the system they describe. This model describes the behaviour of the system. Thanks to the financial support of Alfred Sloan, in 1952 was created the School of Management named after him. It was here that Jay Forrester developed an approach known as System Dynamics (Kozak and Parpan, 2009). The STELLA model itself is a program for non-computer scientists and students.

In recent years, STELLA (Structural Thinking, Experienced Learning Laboratory with Animation) has been developing at a rapid pace to provide comprehensive automation of operations and management functions that address a variety of business challenges and increase the flexibility of software solutions. This program is rapidly evolving due to the emergence of new methodological modeling forms and platforms for simulation experiments.

System as (Kozak and Parpan, 2009) considered is a reality through the interconnections of its elements and indicate that it functions in time and space, and the model is a simplified reflection of this real system to understand its behaviour as a real system. L. Cornwell and R. Costanza (1994) in their work substantiate market mechanisms of environmental management under uncertainty and use the experimental approach and diagram of the STELLA. H. Balali and D. Viaggi (2015) studied how the STELLA model works and how it affects the system and what its results are. For example, other aspects and tendencies, such as: soil studies, biomass forecasts for different environmental scenarios are also performed using the FORKOME computer model (Parpan et al., 2019).

It is important for the economy of the country to what extent in the short term the development of private enterprises will meet domestic needs. In particular, the level of profitability and stability of production will depend on the dynamics of coherence of forecast indicators of development of private enterprises. Multifaceted development of private enterprises requires the organization of their activity based on development of forecasting and detailed predicting of their main performance indicators, in particular: their number, area of agricultural land, the number of employees, net profit and the cost of production manufactured by their, work performed, or services provided. It is based on such predictions it is advisable to pursue an appropriate credit, resource and investment policy to further identify possible ways for the development of private enterprises.

The state of land provision influences on the development of private enterprises whose activity is mainly focused on land use. The importance of land size in the development of private enterprises is indicated by V. Ya. Mesel-Veseliak (2002) so when we make forecasts, we take this metric for analysis. Justification of forecasting the development of private enterprises using a model of optimization of the structure of land resources is considered by I.P. Kudinova (2001). The prediction of agricultural land used by owners-proprietors in agricultural enterprises was made by I. F. Balaniuk and P. Ye. Matkovsky (2010). These studies indicate a trend towards an increase in agricultural land use by agricultural enterprises, a decrease in land area for the personal use of owners-proprietors (Balaniuk et al., 2021a), which will contribute to improved energy efficiency of production and efficient use of wastes (Yakubiv et al., 2019).

The main factors affecting the net profit of private enterprises are the level of cost of production; quality of production, number of employees and their intellectual abilities; sales volumes. The main task of private enterprises is to overcome the negative trends of development, to prevent the decline of production, improve their financial results. Significant role in solving these problems is given precisely to forecasting their activities for the future and based on the data obtained regulating the processes of organization, accounting, and prospective plans to overcome the weak links in their activities.

Therefore, the importance of forecasting the key indicators of their development is relevant. Given the importance of assessing the main indicators of development of private 
enterprises at the national level, it is necessary to predict the profitability and stability of the business, which is the purpose of this study.

\section{Research methods}

STELLA and Statistica 13.1 have been used to forecast the key indicators of private enterprise development. In particular, the relationship between the indicators (variables) that have the strongest influence on the formation of net profit of agrarian enterprises (NET PROFIT) has been investigated. A multivariate analysis has initially been conducted between 6 indicators such as: area of agricultural lands (AREA), profitability level (PROFITABILITY), number of enterprises (ENTERPISE), net profit (NET PROFIT), number of employees (EMPLOYEES), price cost (COST PRICE). All these factors are important in building a net profit forecast system for private enterprises. The result of forecasting is the likely parameters of the state and capabilities of the system for the lead time.

Only 5 indicators in the STELLA program have been selected for simulation, with a $p$ value $\leq 0.05$ (that is, only those rated as statistically reliable). These are such indicators as: area of agricultural lands (AREA), number of enterprises (ENTERPISES), number of employees (EMPLOYEES), cost price (COST PRICE) and net profit (NET PROFIT) values.

After statistical processing of the collected data, a mathematical equation has been obtained that characterizes the connections which appear between the selected indicators. Here we only remark that the collected data has been analyzed for the dependent indicators to exclude cases that could violate the established regression equation. In the result, after eliminating nonsignificant samples, the regression equation is determined. All indicators have been checked for the probability test $\mathrm{p} \leq 0.05$ to exclude those that showed a lack of statistical accuracy (Balaniuk, 2019). The software is component-oriented, in which any objects can play the role of components. Each of them can be both integral and consist of an arbitrary number of other components. Components are connected using simulated situations. In such circumstances, the forecast background has the complexity of determining the degree of its impact on the system.

There converter elements (Converter) were created in the Model: area of agricultural land (AREA), number of Enterprise (ENTERP), number of employees (EMPLOYEES), and value of cost price (COST PRICE). The graphical function (Graphical Function) was used. The graphical element of the STELLA program such as (Graph Pad) and tabular element (Tabel Pad), which show the results of the forecast, were used in the model.

If the stock is rapidly increasing, rapidly decreasing, or held within certain limits, regardless of what is happening around, then there is control mechanism in the system (Forster, 2003). That is, if the model tracks some type of behaviour for a certain period, then it can be concluded that this type of behaviour is based on a certain mechanism that is implemented through the feedback cycle. And if a certain type of behaviour has been present for a long time, then it is a sign that feedback is present in the system (Meadows, 2018).

Acting as a single system, these elements interpenetrate each other, mutually enriching each other, and form a total synergistic potential of the system that exceeds the total effects of the individual elements.

The principle of systematicity implies that the whole process of the STELLA program should be considered as a single whole, consisting of separate constituent elements that are closely interconnected, which in interaction alone, are capable of 
creating the prerequisites for achieving the desired result.

To understand how the system behaves, we have developed graphs of changes in various parameters over time. Due to this, we have got more information than when analyzing individual events. Behaviour graphs over time are also used to determine whether the system is approaching a goal or a boundary, and if so, how fast. The vertical axis may delay the value characterizing a stock or stream. Display schedule form: points at which the direction or shape of the curve changes are also important. In most cases, the form carries more information than the specific axes (Meadows, 2018).

The data from 2000 have been introduced to the model. Data from 2017 were used only for verification of the created model. That is, the model was verificated (results of the forecast for 2017 were compared with real collected data from 2017). A forecast of possible changes of the studied indicators by 2030 has been conducted after verification of the model.

As a baseline, it is accepted that the use of statistics of the State Statistics Service of Ukraine on the activity of private enterprises is required to ensure the correctness of the forecast calculations.

\section{Research results and discussion}

Statistically significant results with $p$ $\leq 0.05$ have been obtained for all 4 analyzed parameters. We see almost zero values of $p$ in the results of regression analysis for the dependent variable NET PROFIT (Table 1).

Table 1. Results of regression analysis for Net Profit

\begin{tabular}{|c|c|c|c|c|c|c|c|c|c|c|c|}
\hline \multirow[b]{2}{*}{$\begin{array}{l}\text { Dependent } \\
\text { Variable }\end{array}$} & \multicolumn{11}{|c|}{ Test of SS Whole Model vs. SS Residual (Arkusz1 in Prywatni pidptyjemdtwa) } \\
\hline & $\begin{array}{c}\text { Multiple } \\
\text { R }\end{array}$ & $\begin{array}{l}\text { Multiple } \\
\text { R2 }\end{array}$ & \begin{tabular}{c||} 
Adjusted \\
R2
\end{tabular} & $\begin{array}{c}\text { SS } \\
\text { Model }\end{array}$ & $\begin{array}{c}d f \\
\text { Model }\end{array}$ & $\begin{array}{c}\text { MS } \\
\text { Model }\end{array}$ & $\begin{array}{c}\text { SS } \\
\text { Residual }\end{array}$ & $\begin{array}{c}d f \\
\text { Residual }\end{array}$ & $\begin{array}{c}\text { MS } \\
\text { Residual }\end{array}$ & $\mathrm{F}$ & p \\
\hline NET PROFIT & 0,960863 & 0,923258 & 0,899645 & 97035996 & & 2425899 & 80657311 & 13 & 620440 & 39,09 & 0,000000 \\
\hline
\end{tabular}

*Source: developed by the authors

Based on Beta, it is estimated that the most significant contribution to the development of agricultural NET PROFIT is such variables as the number of employees (EMPLOYEES) and cost price (COST PRICE) (Table 2).

Table 2. Essential results for Area, Enterpises, Employees and Cost Price

\begin{tabular}{|c|c|c|c|c|c|c|c|c|c|c|}
\hline \multirow[b]{2}{*}{ Effect } & \multicolumn{10}{|c|}{$\begin{array}{l}\text { Parameter Estimates (Arkusz1 in Prywatni pidptyjemdtwa) } \\
\text { Sigma-restricted parameterization }\end{array}$} \\
\hline & $\begin{array}{l}\text { NET PROFIT } \\
\text { Param. }\end{array}$ & $\begin{array}{l}\text { NET PROFIT } \\
\text { Std.EIT }\end{array}$ & $\begin{array}{c}\text { NET PROFIT } \\
t\end{array}$ & $\begin{array}{c}\text { NET PROFIT } \\
\text { p }\end{array}$ & $\begin{array}{l}-95,00 \% \\
\text { CnffLmt }\end{array}$ & $\begin{array}{l}+95,00 \% \\
\text { Cnf.Lmt }\end{array}$ & $\begin{array}{l}\text { NET PROFIT } \\
\text { Beta (ß) }\end{array}$ & $\begin{array}{l}\text { NET PROFIT } \\
\text { St.Err.ß }\end{array}$ & $\begin{array}{l}-95,00 \% \\
\text { Cnf.Lmt }\end{array}$ & $\begin{array}{l}+95,00 \% \\
\text { Cnf.Lmt }\end{array}$ \\
\hline Intercept & 4705,789 & 6643,005 & 0,708383 & 0,491215 & $-9645,55$ & 19057,13 & & & & \\
\hline AREA & $-0,726$ & 2,690 & $.0,269708$ & 0,791618 & $-6,54$ & 5,09 & $-0,051161$ & 0,189690 & $-0,460962$ & 0,358640 \\
\hline ENTERPRIZES & $-1,474$ & 3,638 & $-0,405093$ & 0,691996 & $-9,33$ & 6,39 & $-0,065436$ & 0,161534 & $-0,414410$ & 0,283537 \\
\hline EMPLOYEES & 0,005 & 0,007 & 0,632921 & 0,537760 & $-0,01$ & 0,02 & 0,059824 & 0,094521 & $-0,144376$ & 0,264024 \\
\hline COST PRICE & 0,437 & 0,052 & 8,427506 & 0,000001 & 0,33 & 0,55 & 1,058269 & 0,125573 & 0,786984 & 1,329553 \\
\hline
\end{tabular}

*Source: developed by the authors

The analysis of the standardized endpoints for the dependent variable showed a lack of values of greater than \pm 3 sigma (Picture 1), indicating a lack of significant data deviations. 


\section{Sciendo}

Management Theory and Studies for Rural Business and Infrastructure Development eISSN 2345-0355. 2021. Vol. 43. No. 4: 500-516

Article DOI: https://doi.org/10.15544/mts.2021.45

\section{Picture 1. Results of regression analysis, variable dependent Net Profit}

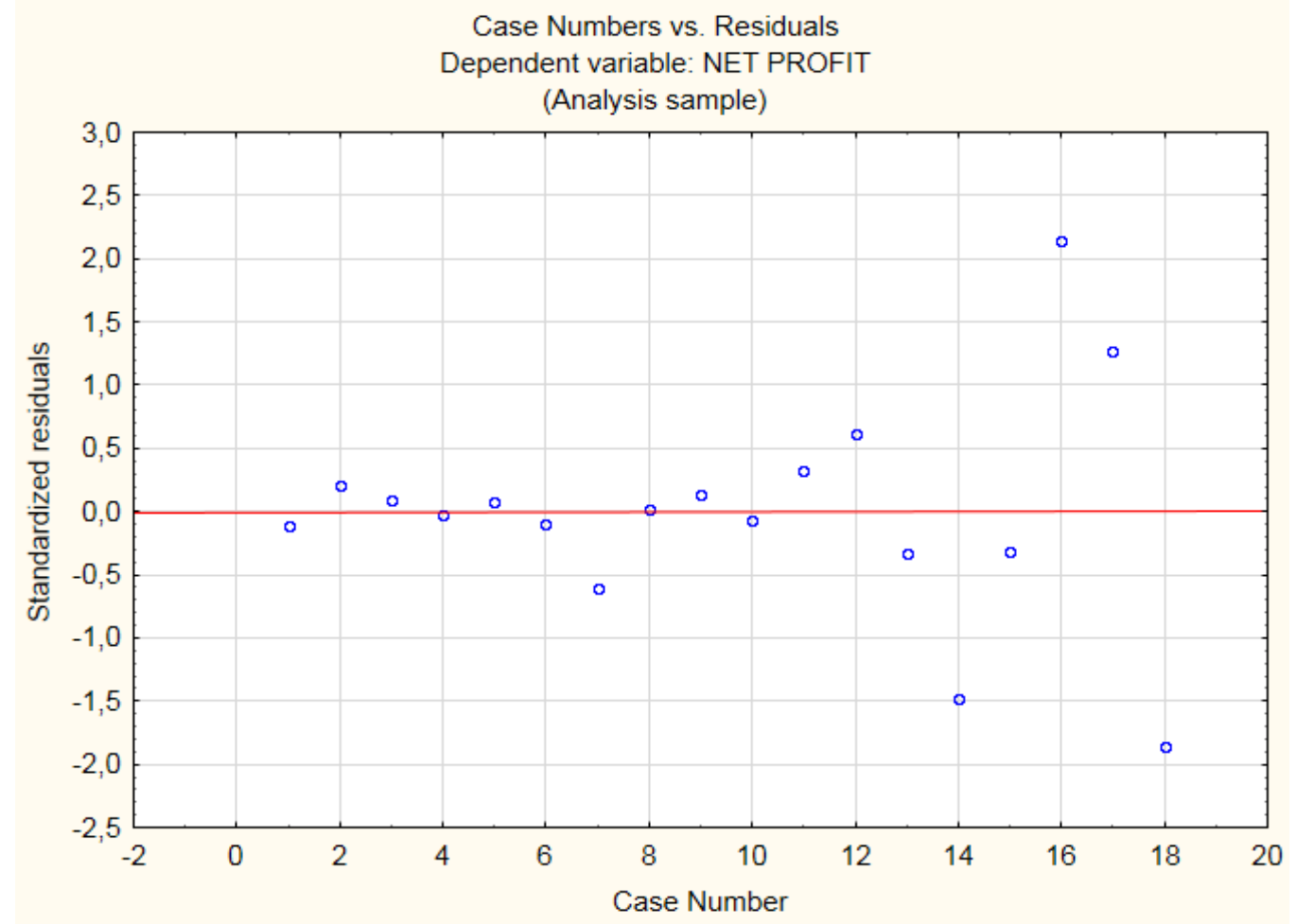

*Source: Developed by the authors

Created in Statistica 13.1. the formula has the following form:

NET PROFIT = 4705.78884875-0.725608354084*AREA-

1.47391186944*"ENTERPRIZES"+0.00451065944474*"EMPLOYEES"+0.437470711082*"COST PRICE"

This formula was inserted into the Inflows NP element (Picture 2) in the model. The figure shows the block diagram of the model. Links between variables are designed as graphic functions in the STELLA program. The convenience of this method is that the appearance of the function can be changed directly on the computer screen with the mouse cursor. We see the production rectangle created in the model as stock (Stock) for agricultural products (UAH mln.). This stock is replenished with Inflows Net profit with a feedback arrow. The Flow is influenced by 3 elements of model (Area, Enterprises, Employees, Cost Price). On the right there is a graph element (Graph Pad) and a table element (Tabel Pad).

Comparison of each stage of the calculation is a prerequisite for research. In addition, the simulation tools allow you to more closely examine the operation of each individual module. The model also allows to show quantitative results of the forecast of net profit of private enterprises.

The design of the STELLA program facilitates the creation of the model by providing the necessary information about the system we are building. The program itself builds a dynamic model of this system. 


\section{Picture 2. The created model in STELLA program}

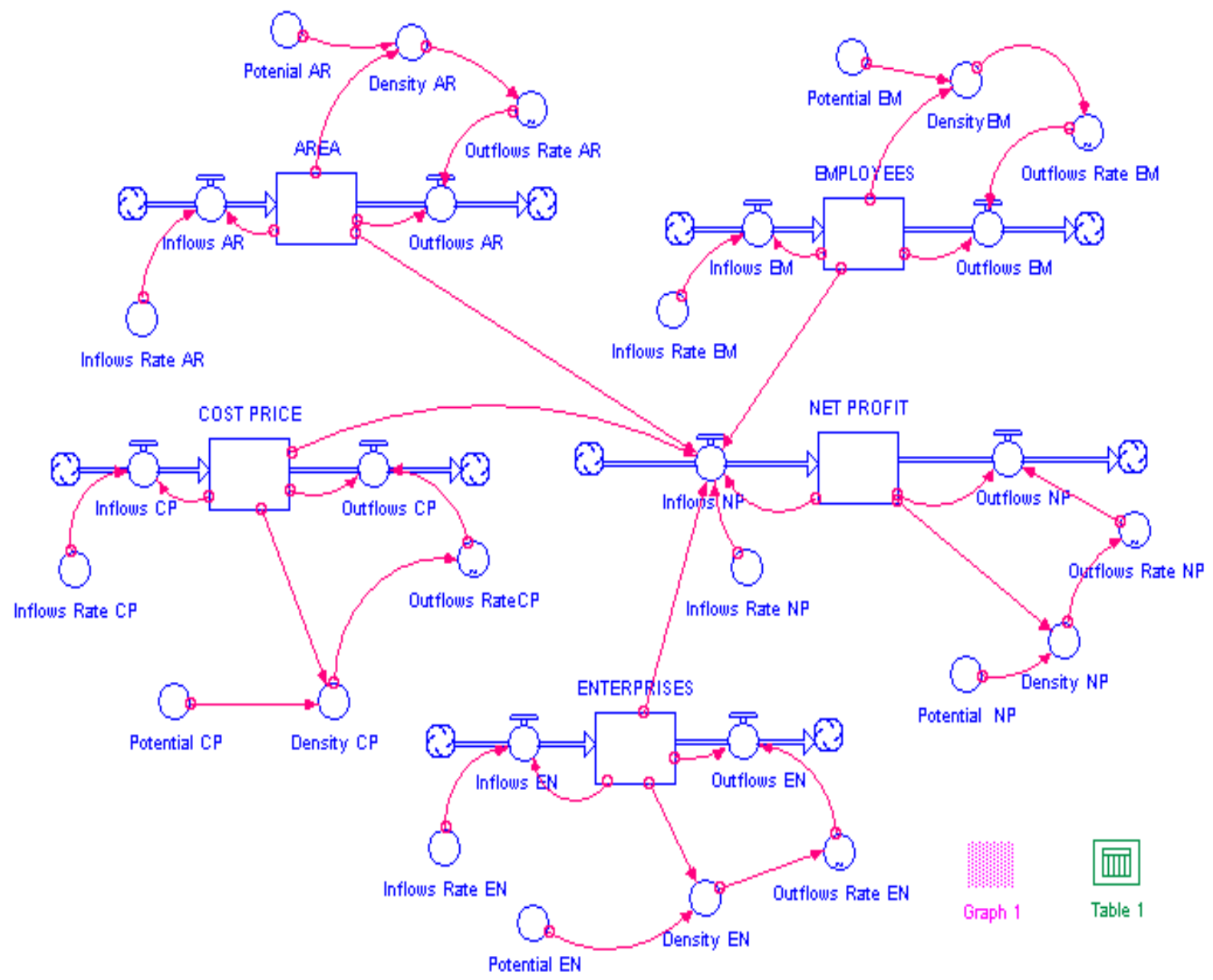

*Source: developed by the authors

Balancing cycles seek to achieve some value to stabilize, each such cycle tries to hold the stock at some level or to some extent. The balancing cycle counteracts any external influence on the system and if the stock is too large, the balancing cycle tries to reduce it, and if the stock is too small, the balancing cycle will increase it (Meadows, 2018).

The arrows in Picture 2 refer to the interactions between individual variables in the model. In STELLA, a solid arrow of links between the elements inside the model represents the link active and describes the course of a particular reaction.

The model's verification consisted of a comparison of actual data from 2017 (as data from 2018 were absent) with data forecasted in the model for 2017. We see that the model for $95-100 \%$ hit the real data in 2017.
The main factor that supports the activity of private enterprises is the resource potential. Among them, land and labour play an important role.

Today, the legislation regulating land and lease relations is being improved in Ukraine. It is aimed at making private use of leased land more efficient and more fertile, and public administrations controlling the fulfilment of their obligations to landlords, for the use of land paying rent in order to protect ownership rights of leased land. Objectively, there is an increasing need for private enterprises to expand their land for business. Ways to expand the land under cultivation are to lease land from the owners of land shares or purchase land. The most important motive for such aspirations is the expansion of the size of private enterprises and the increase of production efficiency. 


\section{Sciendo}

Management Theory and Studies for Rural Business and Infrastructure Development eISSN 2345-0355. 2021. Vol. 43. No. 4: 500-516

Article DOI: https://doi.org/10.15544/mts.2021.45

\section{Picture 3. Graphical representation of forecasting of AREA in STELLA program}

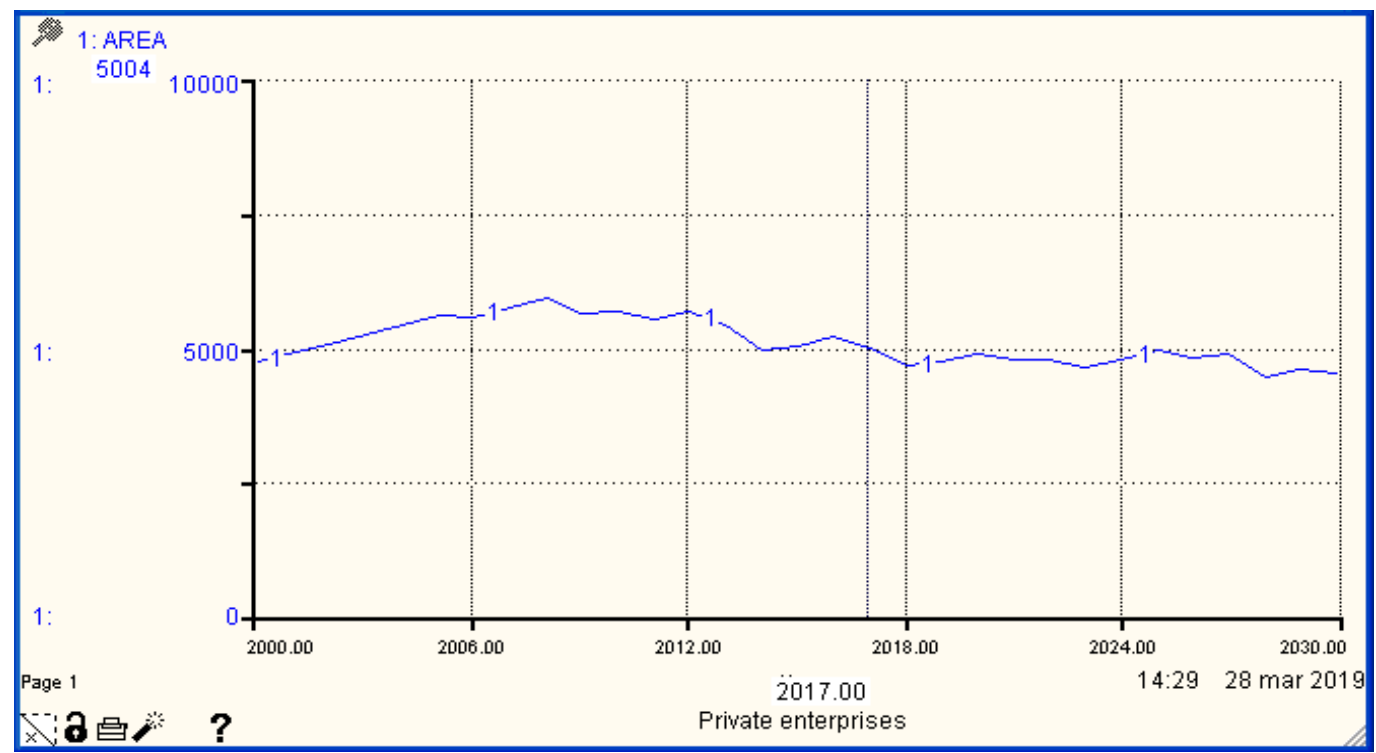

*Source: developed by the authors

Entrepreneurs lease as much land as they can rationally use under certain conditions. First of all, they are defined with a specialization in growing crops that provide the expected results for the future. In the technological aspect, it is important to determine the agricultural condition of the land area and its productive capacity. Taking into account all available conditions, they select the most productive and adapted to these conditions varieties of crops, determine the necessary need for chemicals warehouses, processing plants, etc.

The results of the forecast showed the possible decrease in the AREA (Picture 3) from 4750,0 in 2000 to 4521,96 thousands ha in 2030 (Table 3). In 2017 real statistical data were 5321,9 thousands ha and simulated in the model for verification in this year were 5004,18 thousands ha accordingly. The analyzed variables by 2030 can also be seen in the table (the special character separates the thousands

of values). 
Table 3. Table view of forecasting results for AREA in STELLA program

\begin{tabular}{|c|c|}
\hline Years & |AREA \\
\hline 2000 & $4+750.00$ \\
\hline 2001 & $4 \nmid 907.65$ \\
\hline 2002 & $5+070.54$ \\
\hline 2003 & $5+238.83$ \\
\hline 2004 & $5+412.71$ \\
\hline 2005 & $5+592.35$ \\
\hline 2006 & $5+559.10$ \\
\hline 2007 & $5+743.61$ \\
\hline 2008 & $5+934.24$ \\
\hline 2009 & $5+656.82$ \\
\hline 2010 & $5+672.22$ \\
\hline 2011 & $5+521.83$ \\
\hline 2012 & $5+657.94$ \\
\hline 2013 & $5+421.96$ \\
\hline 2014 & $4+953.50$ \\
\hline 2015 & $5+024.92$ \\
\hline 2016 & $5+191.70$ \\
\hline 2017 & $5+004.18$ \\
\hline 2018 & $4 \nmid 665.82$ \\
\hline 2019 & $4+726.55$ \\
\hline 2020 & $4 \nmid 883.42$ \\
\hline 2021 & $4+783.77$ \\
\hline 2022 & $4+757.62$ \\
\hline 2023 & $4+627.94$ \\
\hline 2024 & $4 \nmid 781.55$ \\
\hline 2025 & $4 \nmid 940.25$ \\
\hline 2026 & $4+822.62$ \\
\hline 2027 & $4+884.20$ \\
\hline 2028 & $4 \nmid 442.09$ \\
\hline 2029 & $4 \nmid 589.52$ \\
\hline Final & $4+521.96$ \\
\hline
\end{tabular}

*Source: developed by the authors

The area of agricultural land of private enterprises in 2017 increased by $12 \%$ compared to 2000 , and it is projected that by 2030 , compared to 2000 , it may decrease by $4.8 \%$.

This is due, first of all, to the gravity of the owners of the land units to selfmanagement in their respective plots without creating a legal entity. The main reason for this is the low rent paid by private companies, which makes it possible for the owner to obtain land in excess of rent by cultivating the land on his own. He goes for it, even knowing that in many cases it will be physically more difficult for him, but the material and financial needs of the family encourage him to make that choice.

In addition, in many cases, the landlords do not renew the lease due to the fact that the tenants due to their financial difficulties are unable to cultivate the leased land and pay their owners the appropriate rent. It happens that there are cases where the peasants, having sufficient for them the size of the land plots, do not cultivate their respective areas of land shares, as a result of which they are vacant.

Owners of private enterprises are personally interested in earning a profit for their work, so to increase production, it is necessary to increase the area of land use. 


\section{Sciendo}

Management Theory and Studies for Rural Business and Infrastructure Development eISSN 2345-0355. 2021. Vol. 43. No. 4: 500-516

Article DOI: https://doi.org/10.15544/mts.2021.45

Positive changes must occur in the use of agricultural land, this primarily concerns the use of land for the intended purpose, lease of the reserve of the land and reserve fund, exchange of land, including unclaimed, adherence to the environmental regime of land use. These measures need to be implemented because of the degradation of land, soils lose their fertility and depletion.

Possible impact on reducing the area of agricultural land in private enterprises will also have a termination of the moratorium on the sale and purchase of agricultural land. Because carefully controlled and metered sale of state-owned agricultural land will promote such a strategy as the development of private enterprises. At the same time, the number of enterprises (Picture 4) increases from 2519 in 2000 to near 3600 enterprises in 2030. In 2017, the statistical data collected were 3215 and simulated in the model for verification in this year were 3018 enterprises respectively.

The overall dynamics reflects a tendency for an increase in the number of private enterprises in 2017, compared to 2000 , by 1.3 times, and by 2030 , compared to 2000 , their growth will be 1.4 times, which is confirms entrepreneurs' interest in starting their own business.

\section{Picture 4. Graphical representation of forecasting of ENTERPRISES in STELLA program}

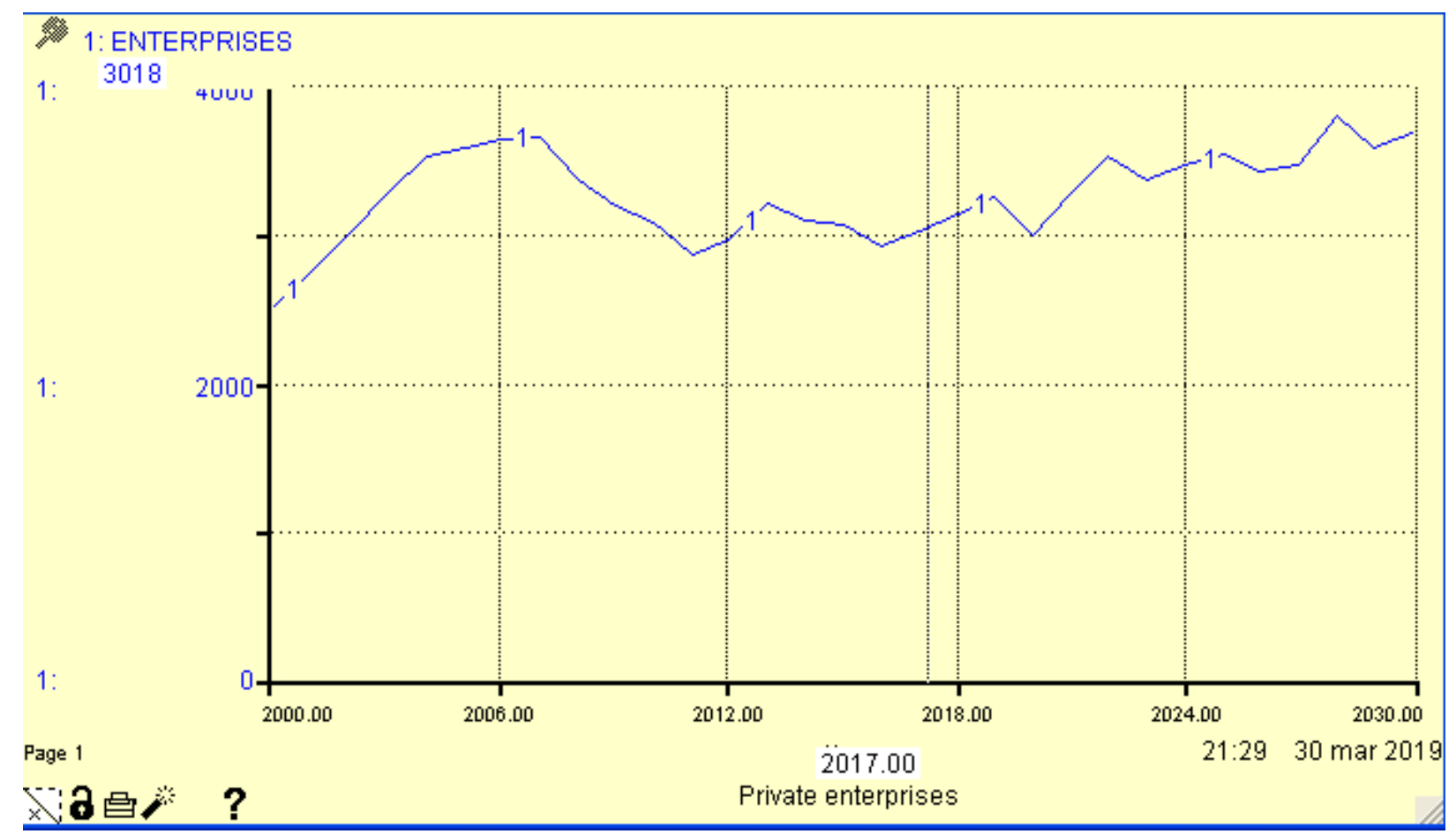

*Source: developed by the authors

The results of the forecast (Picture 5) showed the possible decrease in the number of employees from 455948 in 2000 to 62000 persons in 2030. In 2017 real statistical data were 88112 persons and simulated in the model for verification in this year were 74462 persons accordingly.

The organization of training for agriculture mainly depends on the agricultural system. In Ukraine, various forms of management are developing private enterprises, joint-stock companies, and therefore the whole system of human resources of the agricultural sector is subordinated to them.

Significant reduction in the number of employees of private enterprises occur through the mechanization and automation of 
technological processes in the production, processing and sale of agricultural products. The widespread use of technology leads to the limited need for manual labor, and ultimately to the dismissal of workers.

The activity of organizational and legal forms of agricultural enterprises on a profitable basis, creates prerequisites for the formation of human capital, guarantees social protection of workers, which contributes to improving the prestige of employment in the agricultural sector, improving the standard of living of the rural population by obtaining decent wages.

The reduction in the number of employees of private enterprises in 2017, compared to 2000, was 5.1 times, and a forecast of 2030, compared to 2000, a possible decrease of 7.3 times.

\section{Picture 5. Graphical representation of forecasting of EMPLOYEES in STELLA program}

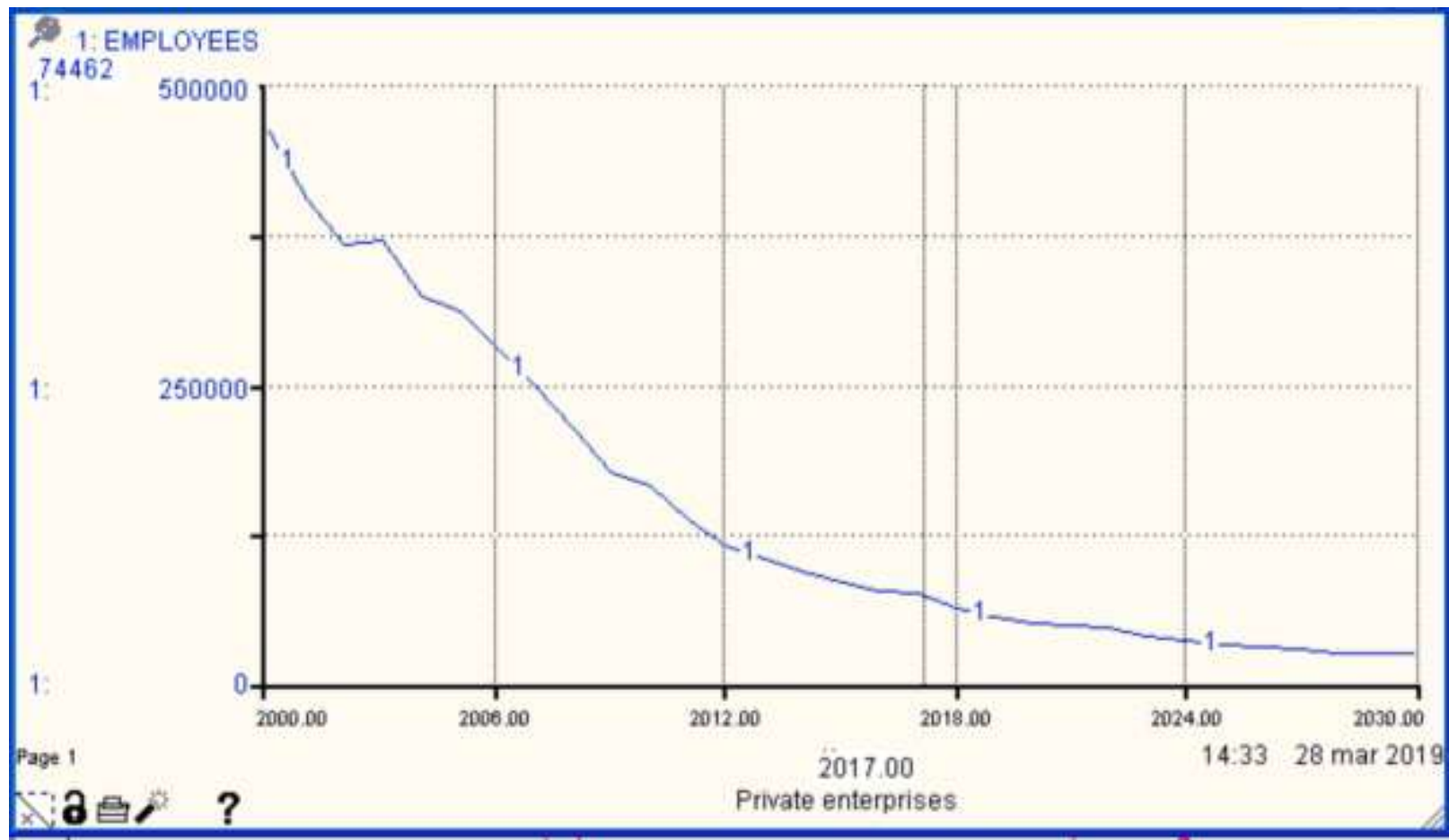

*Source: developed by the authors

At the same time, the increase predicted the cost price (Picture 6) from $2678.2 \mathrm{mln}$ UAH in 2000 to $500985 \mathrm{mln}$. UAH in 2030. In 2017 real statistical data were UAH 65 983,9 million and simulated in the model for verification in this year were 64677 million accordingly. 


\section{Sciendo}

Management Theory and Studies for Rural Business and Infrastructure Development eISSN 2345-0355. 2021. Vol. 43. No. 4: 500-516

Article DOI: https://doi.org/10.15544/mts.2021.45

\section{Picture 6. Graphical representation of forecasting of COST PRICE in STELLA program}

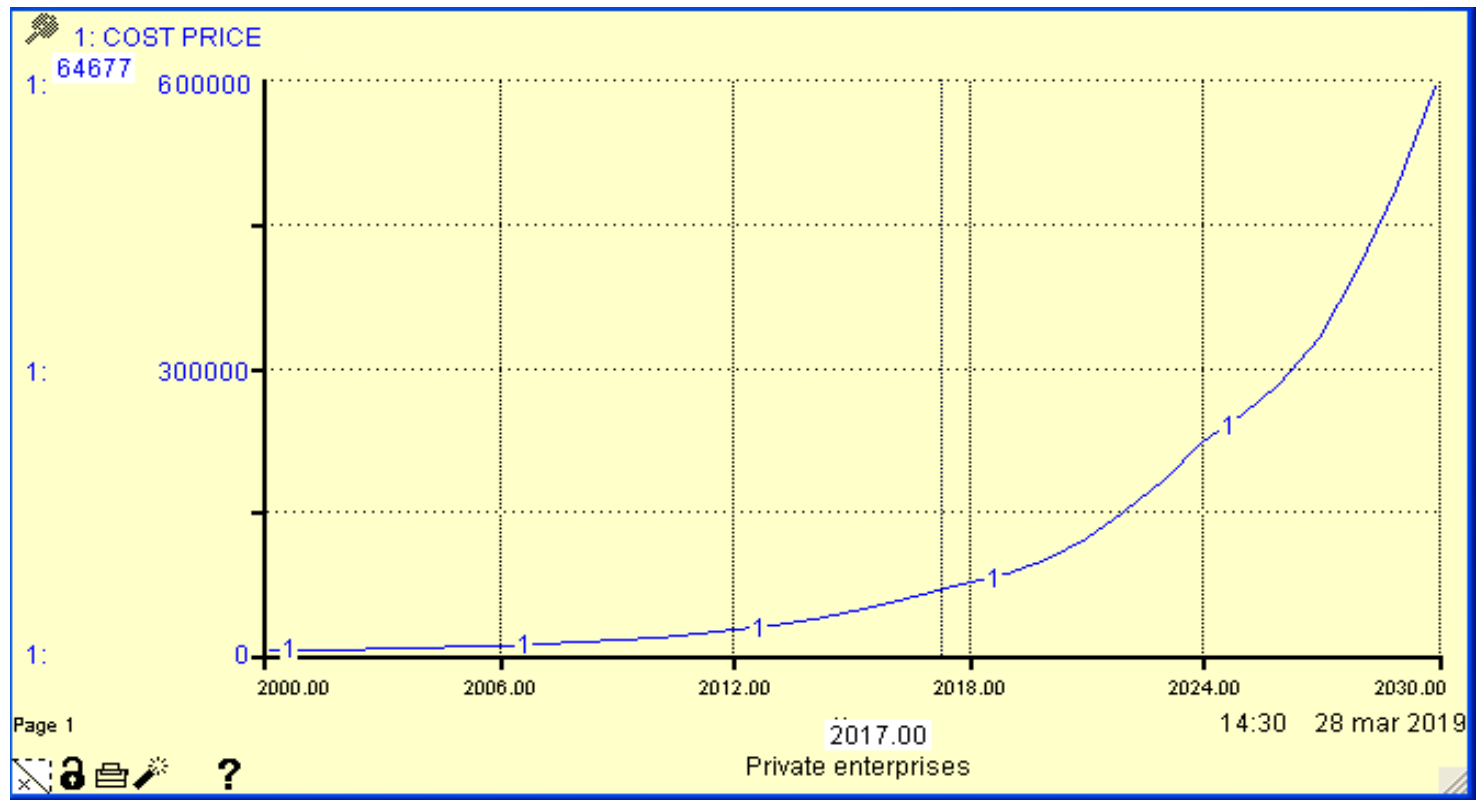

*Source: developed by the authors

The total cost of agricultural products and services of private enterprises in 2017, compared to 2000 , increased 24.6 times, and will increase for 2030. The predicted net profit of private enterprises (Picture 7) is projected to increase from UAH 270.6 million in 2000 to 925356 million UAH in 2030.

From the figure it is clear that one of the main economic prerequisites for increasing the profitability of private enterprises is the capitalization of land and its full incorporation into production. To achieve the forecast indicators of development and to obtain a net profit for Ukrainian private enterprises it is necessary: to use the proper land, property, labour and financial resources effectively and rationally; to diversify production; develop staff motivation; to form new managerial thinking; to introduce new technologies of agricultural production on an innovative basis and to provide services according to the needs of the competitive environment; to provide favourable conditions for entering the domestic and foreign markets. 


\section{Picture 7. Graphical representation of forecasting of NET PROFIT private enterprises in} STELLA program

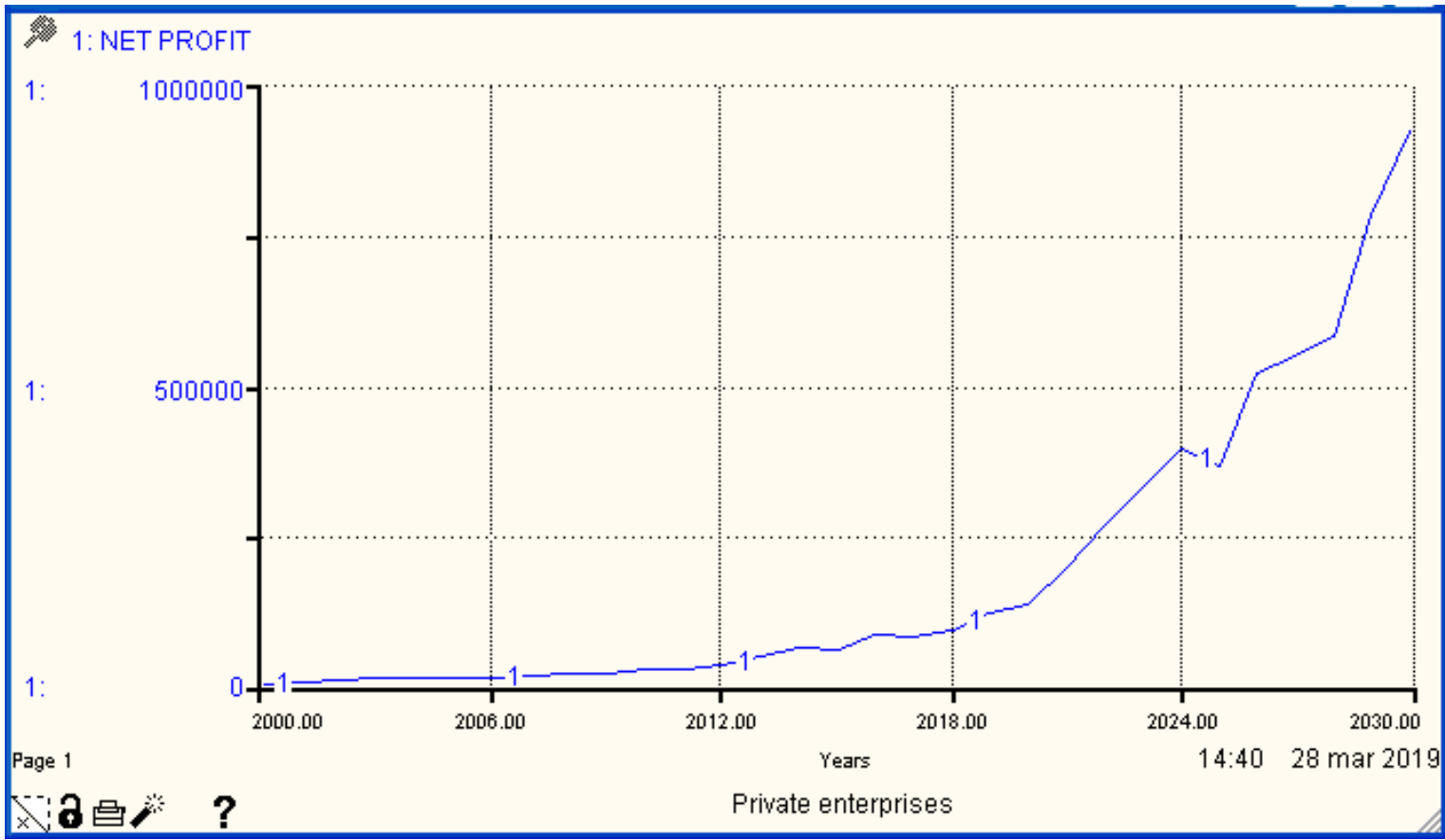

*Source: developed by the authors

The most profitable are the enterprises that spend the most money, live and work and other costs per unit of production. To ensure profitability at enterprises, their owners are constantly looking for and implementing in the production of the latest advanced technologies and organization of labour, the introduction and use of new machines and mechanisms, complex high-speed equipment to improve productivity.

Ensuring that the estimated net profit of private enterprises, which is the basis of the market mechanism of economic activity, is related to the state policy on: legal support of the activity of enterprises in market conditions; stepping up demand for environmentally friendly agricultural products; training of the staff of relevant professions; ensuring equal conditions in competition; encouraging producers to expand playback. Significant interest is shown by producers and processors of agricultural products in forecasting their profitability (Humeniuk et al. 2021).

The model predicts that with the stabilization of the number of private enterprises at 3600 and the area of agricultural land area (Area) lands within 4500 thousand hectares, as well as with the increase in the cost of production of agriculture and services in Ukraine, can be positive changes in the net profit of private agrarian enterprises.

Despite the effective development of private enterprises, large agricultural enterprises remain the largest potential producers of agricultural products, which use more than a third of agricultural land in Ukraine (Mesel-Veseliak, 2002). The increase in landowners among private enterprises increases their access to credit through loans secured by land plots (Paskhaver, Moldavan, 2018).

In the conditions of versatility, human capital is the main systematic factor in the development of private enterprises, that is, a certain number of employees of the relevant professions who are able to provide fullfledged financial and economic activity.

A common problem that impedes the effective management of private agricultural enterprises is the practical unwillingness to prevent personnel risks that form the basis for reducing the productivity of production processes and the deterioration of the quality of finished products. In addition, there are significant marketing risks, which are mainly 
due not only to the dynamics of the agrarian and food markets, but to the late adoption of management decisions, which indicates the "physical" presence of management risks. It can be summed up that a large proportion of losses incurred by private enterprises are caused by the influence of the human factor.

With the introduction of most enterprises of monocultural production and, consequently, owing to the displacement of labor-intensive and auxiliary industries, the need for many workers and professional specialists was eliminated.

Labor supply for private enterprises will be reduced. The reason is the increase of functioning private enterprises with foreign investments, which usually invite specialists from other regions of Ukraine, as well as from abroad, to management positions. Peasants do not always belong to the production staff of such private enterprises because of the lack of knowledge required by modern agricultural technology (Kozak, Parpan, 2009), (Shpykuliak et al. 2019), so they can only be ordinary or seasonal workers (Balaniuk, 2014).

Ignoring the problems of development of private enterprises as a system of rural development leads to a decrease in the efficiency of agricultural production, weakening of the traditionally formed rural system, as well as to the migration of ablebodied population abroad.

Increasing the efficiency of development of private enterprises should be ensured by: the degree of specialization of production, rational provision of equipment, speed of circulation of working capital and reduction of various costs.

Formation of a balanced model of development of the agrarian sector of the Ukrainian economy forecasts for the feasibility of establishing and supporting the development of private enterprises as a priority organizational and legal form of economic management in rural areas.
The defining role of private enterprises is not only to provide the population with quality organic products, but also to increase the level of competitive environment in the agricultural market, to intensify the processes of agrarian deconcentration, to increase employment among the rural population and to form a strong middle class in rural areas.

Priority is given to institutional support for the establishment of private enterprises on the basis of family-type management, which, on the one hand, will overcome the negative social and economic consequences of structural unemployment in rural areas (Zhurakovska et al. 2020), and on the other hand - will approve approaches to the organization of rational use of natural ecosystems in rural areas and responsible attitude of private enterprises for their final business results.

\section{Conclusions}

As a result of existing research methods and models for predicting system dynamics, it was found that one of the most appropriate approaches is to use STELLA software. Models based on system dynamics have a number of advantages, namely: the ability to create a model using the mouse and minimally - the keyboard, the ability to build nonlinear dependencies, the presence of a copy of a fragment of the model, which can be moved to another place, which also has data links elements of the model, adaptation to changes in the environment.

Private enterprises can increase their efficiency by making fuller use of productive resources, including land.

The economic efficiency of private enterprises largely depends on the timely adoption of strategic management decisions, to optimize the process of planning work, increase product quality, improve labor productivity and ensure the sale of goods on favorable terms. 
The conducted studies have led to some forecasts for the development of private enterprises, in particular, the area of agricultural land of private enterprises may decrease by $15 \%$ by 2030 compared to 2017 . The number of private enterprises in 2030 will grow and, compared to 2017, will increase by $12 \%$ to 3600 . That is, most private enterprises, as at this time, will use a small area of agricultural land in 2030-1200 ha. The number of employees by 2030 will decrease and is estimated at 62,000 people compared to 2017 , a reduction will be $29.6 \%$. The increase in the total cost of agricultural products and services in 2030, compared to 2017, may increase by 7.6 times. The net profit of private enterprises in 2030 is projected to increase compared to 2017.

As a result of the forecast for 2030 for the development of private enterprises, it is established that the agricultural sector will gradually lose its labor potential, in spite of the relative stabilization of their number and area of agricultural land. At the same time, in private enterprises there is an increase in net income, mainly due to the increase in the cost of agricultural products and services, which affects the revenue for products sold and services rendered. The forecast showed changes that may occur in the agricultural sector of Ukraine because of private enterprise activity.

However, we can systematically observe the problems of securing the number of employees of private enterprises.

The forecast outlined in the paper can be practically implemented in the functioning of private enterprises, is scientifically sound, understandable in use, which makes it accessible to scientists and business leaders. The simulation results are presented in the form of graphs and tables and on the so-called displays that show the current values of some variables during the simulation.

The strength of the foundation depends on the prospect of further action to support the development of private enterprises. That is why the resource base is the decisive prerequisite for their formation.

\section{References} $68-74$.

Babych, M. M. (2007). Legal support of functioning of farms // The Economy of Agro-Industrial Complex, 12:

Balali, H. \& Viaggi, D. (2015). Applying a System Dynamics Approach for Modeling Groundwater Dynamics to Depletion under Different Economical and Climate Change Scenarios // Water, 7: 5258-5271. https://doi.org/10.3390/w7105258

Balaniuk, I., Kozak, I., Shelenko, D., Balaniuk, S. \& Kozak-Balaniuk, I. (2019). Forecasting of Gross Agricultural Output of Agrarian Enterprises of Ukraine: Case Study with STELLA Software // Economic Studies (Ikonomicheski Izsledvania), 28(5): 148-163.

Balaniuk, I., Kozak, I., Balaniuk, S., Kozak-Balaniuk, I., Sas, L. \& Shelenko, D. (2021a). The role of united territorial communities in the functioning of agricultural enterprises // Management Theory and Studies for Rural Business and Infrastructure Development, Vol. 43. No. 1: 52-66. - https://doi.org/10.15544/mts.2021.05

Balaniuk, I., Kyrylenko, V., Chaliuk, Y., Sheiko, Y., Begun, S. \& Diachenko, L. (2021b). Cluster analysis of socio-economic development of rural areas and peasant farms in the system of formation of rural territorial communities: a case study of Volyn region, Ukraine // Scientific Papers Series Management, Economic Engineering in Agriculture and Rural Development. 21(3): 177-188.

Balaniuk, I. F. \& Matkovskii, P. Ye. (2010). Forming of the lands owner in agrarian sector of economics. IvanoFrankivsk: Vasyl Stefanyk Precarpathian National University.

Balaniuk, S. I. (2014). Systematic unity of development of households and rural areas, Ivano-Frankivsk: LIK.

Blazy, J. M., Tixier, P., Thomas, A., Ozier-Lafontaine, H., Salmon, F. \& Wery, J. (2010). BANAD: A farm model for ex ante assessment of agro-ecological innovations and its application to banana farms in Guadeloupe // Agricultural Systems, 103 (4): 221-232 - http://publications.cirad.fr/une_notice.php?dk =553928 [2021 0504$].$

Clark, J. K., Munroe, D. K., \& Mansfield, B. (2010). What counts as farming: how classification limits regionalization of the food system // Cambridge Journal of Regions, Economy and Society, 3(2): 245-259. https://doi.org/10.1093/cjres/rsq018.

Cornwell, L. \& Costanza, R. (1994). An experimental analysis of the effectiveness of an environmental assurance bonding system on player behaviour in a simulated firm // Ecological Economics. 11: 213-226.

Economic Code of Ukraine. (2003). - https://zakon.rada.gov.ua/laws/show/436-15 [2020 20 06]. 
Management Theory and Studies for Rural Business and Infrastructure Development

eISSN 2345-0355. 2021. Vol. 43. No. 4: 500-516

Article DOI: https://doi.org/10.15544/mts.2021.45

Forester, Dzh. (2003). World Dynamics Moscow. Moscow: AST; St. Petersburg: Terra Fantastica, 2003. 379 r.). - https://platona.net/load/knigi_po_filosofii/sinergetika/forrester_d_mirovaja_dinamika_2003/55-1-0-4650 [2021 22 03].

Frańczuk, M. (2019). Codes of banking ethics and banking soft law in Poland // Journal of Vasyl Stefanyk Precarpathian National University, 6(2): 49-54. - https://doi.org/10.15330/jpnu.6.2.49-54.

Gupta, P. S. (2019). The entwined futures of financialisation and cities. // Cambridge Journal of Economics, 43(4): 1123-1148. - https://doi.org/10.1093/cje/bez028.

Humeniuk, M., Shelenko, D., Nemish, D. \& Balaniuk, I. (2021). Improving the efficiency of agricultural entrepreneurship by processing rapeseed to biodiesel // Scientific Papers Series Management, Economic Engineering in Agriculture and Rural Development, 21(3): 431-438.

Kozak, I. \& Parpan, V. (2009). Ecological modelling using STELLA program. Ivano-Frankivsk: Plai.

Kudinova, I. P. (2001). Modeling the structure of land resources of enterprises of different forms of ownership // Organizational and economic problems of agribusiness development. 2: 294-297.

Medouz, D. (2018). Azbuka systemnoho myslennia. "Mann, Ivanov i Ferber". - https://iptmnntu.ru/dl/books/Системная\%20 динамика/Azbuka-sistemnogo-myshleniya.pdf [2019 24 09].

Mesel-Veseliak, V. Ya. (2002). Legal forms of management and their effectiveness // Agroindustrial Complex of Ukraine: Current Trends and Prospects. Information and analytical collection, 5: 449-463.

Parpan, T., Kozak, I., Shparyk, Y., Mylenka, M. \& Balaniuk, I. (2019). Simulation of decline of Norway spruce (Picea abies L. Karst.) forests in Gorgan Mountains (Ukrainian Carpathians): case study using FORKOME model // Ekológia (Bratislava), 38(4): 353-366. - https://doi.org/10.2478/eko-2019-0026.

Paskhaver, B. Y. \& Moldavan, L. V. (2018). Land capital. Agrarian and rural development for growth and renewal of the Ukrainian economy: a scientific report. NAS of Ukraine, State Institution «Inst. and predicted. NAS of Ukraine. Kyiv: 33-41.

Perehudov, D. O., Sieliukov, O. V., Krykhta, V. V. \& Krasnik, A. A. (2009). Analysis of features of application and classification of forecasting methods in the field of development of networks and telecommunication technologies. // Visnyk $\quad$ DUIKT, $\quad 7(1): \quad 27-40 . \quad$ - $\quad$ http://irbis-nbuv.gov.ua/cgibin/irbis_nbuv/cgiirbis_64.exe?C21COM=2\&I21DBN=UJRN\&P21DBN

$=$ UJRN\&IMAGE_FILE_DOWNLOAD=1449-463. [2020 05 02].

Pylypiv, N. I., Maksymiv, Yu. V. \& Piatnychuk, I. D. (2018). Conceptual approach to construction of accounting and information provision of social responsibility for business enterprises through the prism of the business partnership system. Financial and credit activity: problems of theory and practice, 4(27): 201-211. - https://doi.org 10.18371/fcaptp.v4i27.154374.

Sokolovska, Z. \& Kapustian, I. (2018). Modeling the advertising strategy of enterprises on the pharmaceutical products market. Ed.: M. Zveryakov (ed.-in-ch.) and others // Socio-economic research bulletin; Visnik social'noekonomičnih doslidžen' (ISSN 2313-4569), Odessa National Economic University, Odessa, No. 1 (65): $217-226$.

Stasiv, O. F. (2010). Improvement of forms of management in agriculture // Economic Sciences. Accounting and Finance Series. 7 (25), P. 3: 236-246.

Shpykuliak O. \& Bilokinna I. (2019). "Green" cooperatives in the formation of an institutional mechanism of evelopment of alternative power engineering in the agrarian sector of the economy // Baltic Journal of Economic Studies, No. 2. (5): 249-255. - https://doi.org/10.30525/2256-0742/2019-5-2-249-255.

Yakubiv, V., Panukhnyk, O., Shults, S., Maksymiv, Y., Hryhoruk, I., Popadynets, N., Bilyk, R., Fedotova, Y. \& Bilyk, I. (2019). Application of Economic and Legal Instruments at the Stage of Transition to Bioeconomy // Advances in Artificial Intelligence, Software and Systems Engineering. AHFE Advances in Intelligent Systems and Computing. Springer Nature Switzerland. In: Ahram T. (eds), 965: 656-666. - https://doi.org 10.1007/978-3-030-20454-9_64.

Yakubiv, V. \& Boryshkevych, I. (2018). Strategic analysis of the development of renewable energetics in the world and in Ukraine // Journal of Vasyl Stefanyk Precarpathian National University, 5(3-4): 33-43.

Zhurakovska, I. V., Sydorenko, R. V. Shmatkovska, T. O. \& Brodska, I. I. (2020) Factors of influence on employment in small and medium-sized business in Ukraine // Financial and credit activity-problems of theory and practice, 1(32): 109-119. 